\title{
Synthesis of functionalized benzyl amines by the reductive alkylation of heterocyclic and heteroaromatic amines with arylaldehydes and preparation of the intermediates for new synthetic biomolecules
}

\author{
Janna Ignatovich, Klaudiya Gusak, Vitaliy Kovalyov, Nikolay Kozlov, \\ and Elena Koroleva* \\ Institute of Chemistry of New Materials, The National Academy of Sciences of Belarus, 36 \\ Skorini st., Minsk 220140, Republic of Belarus \\ E-mail: evk@ichnm.basnet.by
}

Dedicated to Professor Oleg Kulinkovich on the occasion of his $60^{\text {th }}$ birthday

\begin{abstract}
With the object of synthesis of benzyl derivatives of heterocyclic amines, we have investigated the reaction of amines 1, 2, 10-12 and arylaldehydes 3, 4 in the presence of different reducing agents. The improved procedure for the reductive alkylation of heterocycle containing primary amines or heterocyclic secondary amines has been elaborated for synthesis of new benzyl derivatives 7-9 and 16-18. These benzyl amines have been obtained in 50-75\% yields by direct reductive amination of arylaldehydes with sodium borohydride - acetic acid reducing system.
\end{abstract}

Keywords: Heterocyclic amines, benzyl derivative, reductive alkylation

\section{Introduction}

Amines and their derivatives are important functionalities in various natural and synthetic biomolecules. Due to its unique biological properties the amine moiety plays a central role in chemotherapeutics of numerous diseases. ${ }^{1}$ Considering their numerous applications in the fields of medical, bioorganic and synthetic organic chemistry, there has been tremendous interest in synthesis of new bioactive amines and developing efficient methods for their derivatives. Derivatives of 2-aminopyrimidine, 6-aminoquinoline, 1-methylpiperazine, morpholine are used as the key organic intermediates for synthesis of biomolecules. ${ }^{2}$ For synthetic purposes, we were interested in preparation of some functionalized derivatives of these heterocyclic amines. ${ }^{3}$ Herein we report the results of synthesis of benzyl amines and a practical procedure for their preparation. 
Many methods have been developed for the preparation of benzyl amines involving: alkylation of amines with aralkyl halides, ${ }^{4}$ or reductive amidation of carbonic acid derivatives, ${ }^{5}$ or amination of aldehyde derivatives. ${ }^{6}$ The reductive amination of carbonyl compounds (or the reductive alkylation of amines) is one of the most useful methods of synthetic organic chemistry, which provides an access to structurally diverse amines. ${ }^{6 \mathrm{~d}}$ The reaction of aldehyde with primary or secondary amine proceeds through the formation of imine or iminium salt followed by in situ reduction to an amine of higher order. This reaction allows the conversion of carbonyl functionality to an amine by directly treating a mixture of the carbonyl compound and the amine with suitable reducing agents in single operation (direct reductive amination) without preformation of an intermediate imine or iminium salt.

Many different metal hydride agents for this reduction have been reported in the literature. ${ }^{7}$ Nevertheless the reductive amination of formic derivative with heterocyclic amine usually leads to tertiary amine in small yield with the exception of catalytic reduction under pressure of hydrogen. ${ }^{6 \mathrm{a}, 6 \mathrm{~b}, 7 \mathrm{a}}$ The Borch reduction using sodium cyanoborohydride ${ }^{7 \mathrm{~b}}$ and reductive amination with triacetoxyborohydride ${ }^{7 f}$ are very effective methods, but the use of these reducing reagents has many limitations. The Borch reductive alkylation method is less effective when both the ketone and the amine are expensive or iminium intermediate difficult to form. Sodium triacetoxyborohydride has limitation with aromatic carbonyl compounds.

\section{Results and Discussion}

With the object of preparation of new intermediates for biomolecules, the functionalized benzyl amines, we have searched effective procedure for their synthesis and have investigated the reaction of reductive alkylation of amines 1, 2, 10-12 with arylaldehydes 3, 4 in the presence of different reducing agents - $\mathrm{HCOOH}, \mathrm{NaCNBH}_{3}, \mathrm{NaBH}_{4}, \mathrm{NaBH}_{4}-\mathrm{NiCl}_{2}, \mathrm{NaBH}_{4}-\mathrm{Ti}(\mathrm{OPr}-\mathrm{i})_{4}$ and others.

The results of reductive amination of arylaldehydes with secondary heterocyclic amines (1methylpiperazine, morpholine and others) with $\mathrm{HCOOH}, \mathrm{NaCNBH}_{3}, \mathrm{NaBH}_{4}-\mathrm{NiCl}_{2}$ as reducing agents we described earlier. ${ }^{8}$ However, these reagents had either one drawback or another. For example, when $\mathrm{NaCNBH}_{3}$ was used as the reducing agent for reductive amination, a mixture of products was formed. Reductive amination of arylaldehydes with formic acid by LeuckartWallach reaction is effective route to benzyl derivatives. ${ }^{8 a}$ But its conditions (high temperature, 190-210 ${ }^{\circ} \mathrm{C}$ ) limited the scope of reaction.

Herein we report a practical procedure for the preparation of benzyl derivatives of heterocyclic, heteroaromatic and/or aromatic amines. We have found that $p$-nitroaniline 10, primary amines 11, 12 or secondary amines - 1-methylpiperazine 1, morpholine 2, and arylaldehydes 3, 4 were reacted with an excess of $\mathrm{NaBH}_{4}$ in the presence of acetic acid, thus the corresponding benzylamines 7-9, 16-18 have been isolated in good yields. 
One-pot reductive amination procedure was carried out as follows: a mixture of arylaldehyde and amine in methanol or benzene in the presence of acetic acid was stirred for one hour and then sodium borohydride was added at $0--5{ }^{0} \mathrm{C}$ followed by being stirred for $10-12 \mathrm{~h}$. In all the cases prior to addition of reducing agent the arylaldehyde and amine were kept $1-2 \mathrm{~h}$ to ensure complete imine formation. TLC evaluated the reaction results.

The interaction of aldehyde and secondary amine in the presence of acetic acid occurs evidently through the iminium salt 5 formation ${ }^{7 \mathrm{~b}, 9}$ followed by its reduction to benzyl amine with $\mathrm{NaBH}_{4}$ (Scheme 1). Reduction of iminium salt in situ gives satisfactory yields of tertiary amines. It was revealed that the optimal reaction conditions were using $\mathrm{MeOH}$ as solvent and $\mathrm{AcOH}$ for iminium salt formation.
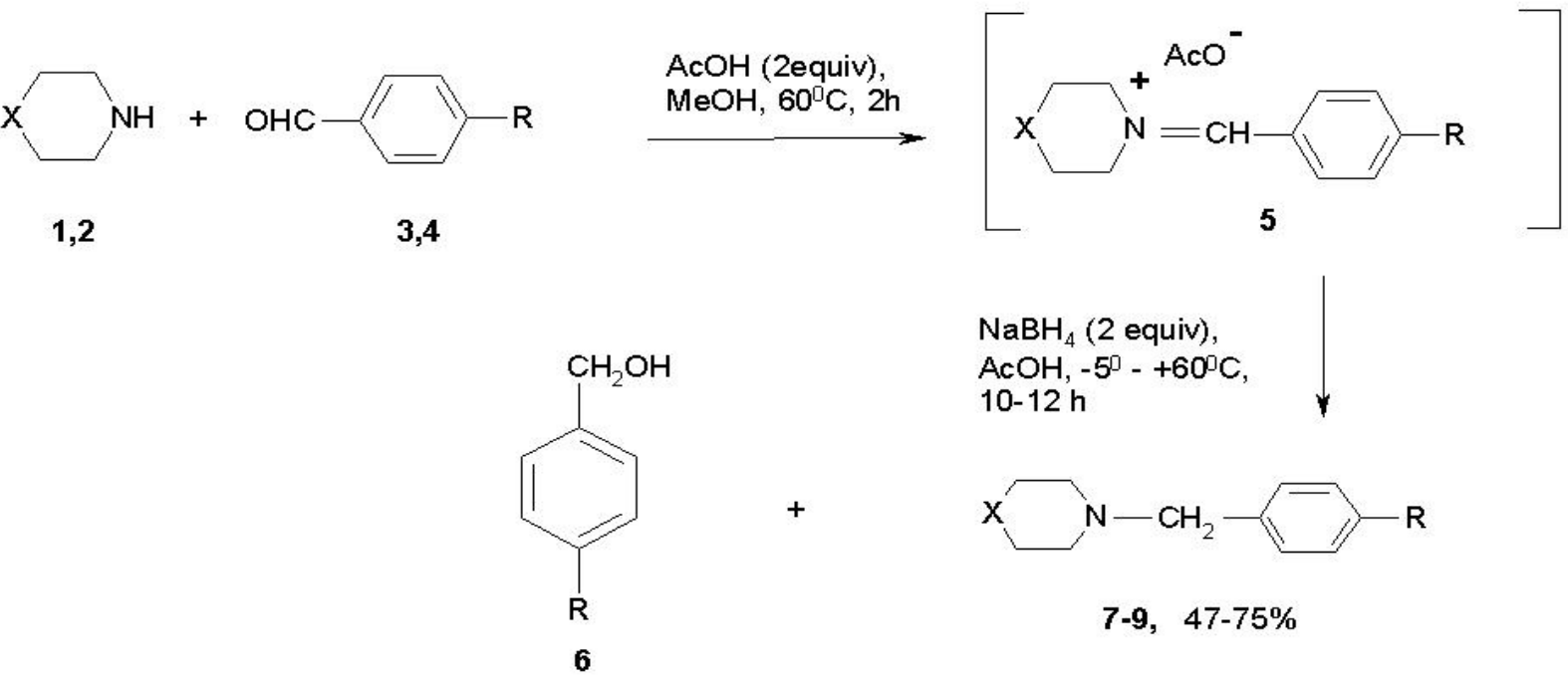

$1,7,8 \mathrm{X}=\mathrm{NMe} ; 2,9 \mathrm{X}=\mathrm{O} ; 3,6,7,9 \mathrm{R}=\mathrm{COOMe} ; \mathbf{4 , 8} \mathrm{R}=\mathrm{NO}_{2}$

\section{Scheme 1}

It was found that yields of products obtained 7-9 were dependent on a mixing order and period of aldehyde and amine preliminary contact before adding of reducing agent. So, sodium borohydride must be added after the iminum intermediate had been stabilized as salt $\mathbf{5}$. We noticed that sodium borohydride addition in reaction mixture had been less effective and resulted in increasing of benzyl alcohol yield in some cases, the product of competitive reduction of aldehyde. The unexpected 4-methoxycarbonylbenzyl alcohol 6 produced in 90\% yield from the reaction of morpholine 2 and 4 -formylbenzoate 3 prompted us to change the procedure of reductive alkylation of morpholine and others.

So, procedure of direct reductive amination was elaborated as follows: a mixture of arylaldehyde and amine in methanol or benzene in the presence of $\mathrm{AcOH}$ was kept one-two hours to ensure complete imine formation. Then the mixture was added at $0--5{ }^{0} \mathrm{C}$ to reducing system which was prepared preliminary by mixing sodium borohydride and acetic acid in a 1:3 
molar ratio at $0{ }^{0} \mathrm{C}$ in benzene. Then the mixture has being stirred under reflux for $10-12 \mathrm{~h}$. In general, 1.0 equivalent of amine and 1.0 equivalent of arylaldehyde and an excess of sodium borohydride were used. The products were isolated by extraction with AcOEt from the reaction mixture after preliminary extraction of acidic by-products and starting substances.

This improved protocol has been used in the preparation of amine 8 containing nitro group. So, the reductive amination 4-nitrobenzaldehyde 4 with 1-methylpiperazine was occurred and the benzyl amine 8 was obtained.

The interaction between aldehyde 3 and primary amines 10-12 proceeds evidently through Schiff bases 13-15 formation followed by their reduction in situ to form benzyl amines 16-18. The reaction of amines 10-12 and 4-formylbenzoate 3 with $\mathrm{NaBH}_{4}$ was performed both without isolation of the Schiff bases and with their prior isolation (Scheme 2):

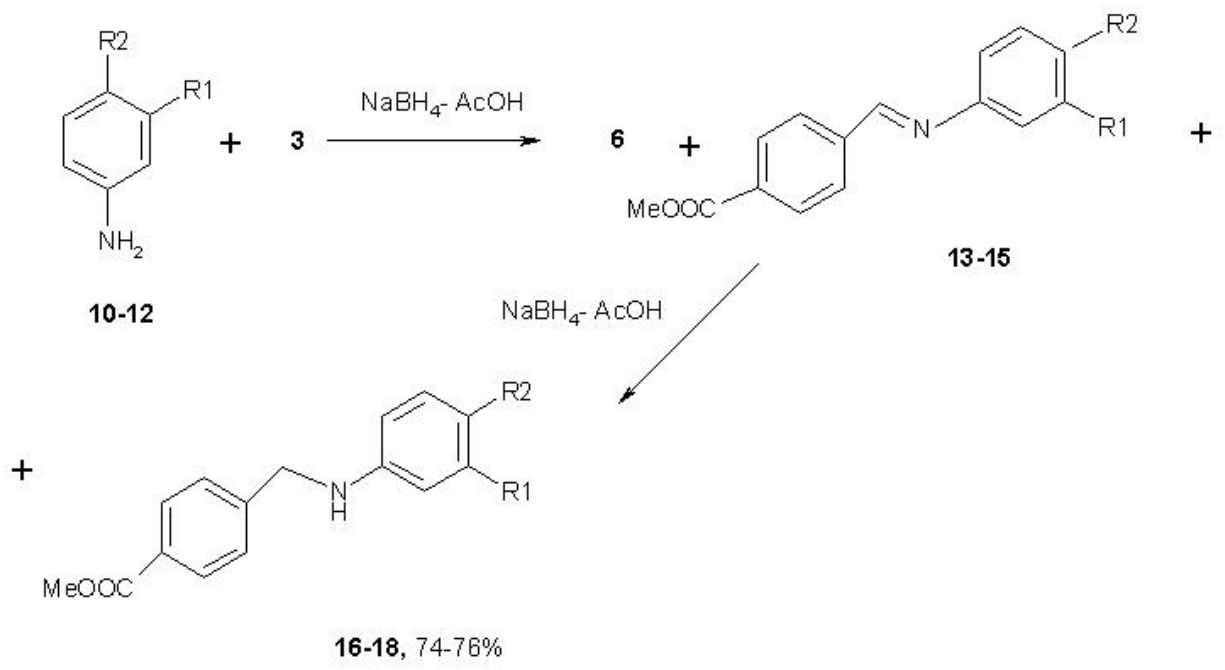

10,13,16: $\mathrm{R}^{1}=\mathrm{H}, \mathrm{R}^{2}=\mathrm{NO}_{2} ; 11,14,17: \mathrm{R}^{1}, \mathrm{R}^{2} \mathrm{C}_{6} \mathrm{H}_{3}=$ quinolin-6-yl; 12,15, 18: $\mathrm{R}^{1}=2$-[4-(pyridin-3-yl)pyrimidinyl]amine, $\mathrm{R}^{2}=\mathrm{Me}$

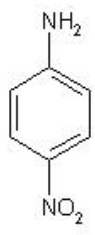

10<smiles>Nc1ccc2ncccc2c1</smiles>

11

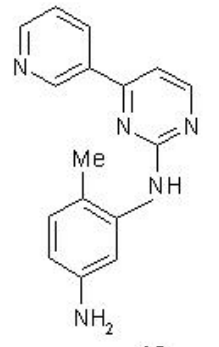

12

\section{Scheme 2}

Direct alkylation of electron-deficient amines 10-12 was carried out by addition the mixture of arylaldehyde and amine in benzene which was kept a few hours to preliminary prepared the 
sodium borohydride - acetic acid reducing system also. Direct alkylation occurs in some instances where the factors for formation of Schiff bases are unfavorable (entry 10,12 ).

The other route was a stepwise reaction which involved separate step of the imines obtaining followed by the reduction of these imines 13-15. The Schiff bases 13-15 were prepared by the condensation of amines 10-12 with aldehyde $\mathbf{3}$ in alcohol solution in accordance with literature methods in $80-85 \%$ yields. The compounds 13-15 were reduced with difficulty in comparison with fresh prepared ones and in situ added to reducing system before beginning of imines 13-15 precipitation.

The experimental data are in accordance with assumption that the sodium borohydride acetic acid reducing system forms the triacetoxyborohydride as acting molecule. This interpretation agree to the hypothesis P.Marchini et al. ${ }^{10}$ Probably the imines 13-15 salt or iminium salt 5 are actually reduced by $\mathrm{BH}_{4}^{-}$also; this hypothesis may account for the rapid reduction under relatively acidic conditions as compared to the relatively slow reduction of isolated Schiff base. ${ }^{11}$

Under the reaction conditions it was possible to provide the reductive amination of arylaldehydes with deactivated heterocyclic amines. In all cases better results were obtained with primary amines compared to the secondary ones.

The benzyl amines 7-9 were isolated by usual acid-base treatment of reaction solution followed by extraction and not required further purification. The solid benzyl amines 16-18 were purified by the recrystallization. The ${ }^{1} \mathrm{H}$ NMR, ${ }^{13} \mathrm{C}$ NMR, IR and mass spectra are in complete agreement with structures 16-18.

The $\mathrm{NaBH}_{4}-\mathrm{AcOH}$ reducing system was found to be the most effective agent for imine and iminium salt reduction. It was tolerated to formyl, nitro and carboxyl groups in reaction conditions, and the formation of byproducts haven 't been observed. This improved protocol may be used in the preparation of amines containing nitro group. So, the reductive amination of 4nitrobenzaldehyde $\mathbf{4}$ and reductive alkylation of $p$-nitroaniline $\mathbf{1 0}$ were occurred with the obtaining the nitro derivatives of amines 8, 13, 16.

In conclusion, we have developed a practical procedure for the synthesis of benzyl amines. In light of its simplicity and use of affordable reagents, this method is expected to have use for giving other heterocyclic amines also. Sodium borohydride is a very common and safe reagent for this reaction. Derivatives 7-9, 14, 15, 17, 18 are the key synthetic intermediates of bioactive derivatives and some drugs, ${ }^{1 \mathrm{~d}, 2,4 a}$ in particularly the imatinib mesylate, a new drug of chronic myeloid leukemia. ${ }^{1 \mathrm{c}}$ The total synthesis of new bioactive compounds from these precursors are now under way in our laboratory.

\section{Experimental Section}

General Procedures. ${ }^{1} \mathrm{H}$ NMR and ${ }^{13} \mathrm{C}$ NMR spectra were recorded on Bruker AC-500 spectrometer at $500 \mathrm{MHz}$ and $125 \mathrm{MHz}$, respectively. Chemical shifts $(\delta)$ are given from TMS $(0$ 
ppm) as internal standard for ${ }^{1} \mathrm{H}-\mathrm{NMR}$, and $\mathrm{CDCl}_{3}(77.0 \mathrm{ppm})$ for ${ }^{13} \mathrm{C}-\mathrm{NMR}$. TLC was carried out on Merk DC-Plasticfolien Kieselgel $60 \mathrm{~F}_{254}$, butanol:ethanol: $\mathrm{NH}_{4} \mathrm{OH}$ 8:1:1. IR spectra were recorded on FTIR spectrophotometer Nicolet Protégé-460. Mass-spectra were measured on gas chromatograph Agilent Technologies 6850 series with mass detector Agilent Technologies 5973 series. The melting points were determined on Boetius block and are uncorrected. All products were purified by means of crystallization or column chromatography on silica gel (10\% methanol/chloroform). The reported yields are given for purified compounds. All substances had NMR, mass-, IR spectra and elemental analyses consistent with the assigned structures.

The reagents and solvents were of commercial quality. The starting substances were used as commercially supplied, expect for amines 11, 12 which were prepared via literature adapted procedures. 6-Aminoquinoline 11 was synthesized by reduction of 6-nitroquinoline with $\mathrm{SnCl}_{2}{ }^{12}$ 4-methyl- $N^{3}$-(4-pyridin-3-ylpyrimidin-2-yl)benzene-1,3-diamine $\mathbf{1 2}$ was synthesized by reduction of $\mathrm{N}$-(2-methyl-5-nitrophenyl)-4-pyridin-3-ylpyrimidin-2-amine according to the reported procedure ${ }^{1 \mathrm{c}}$. Imines 13, 14 were synthesized by the condensation of amine 10, 11 with aldehyde 3 in alcohol solution in $80-85 \%$ yields according to the reported procedure. ${ }^{12}$

\section{General procedure for the direct reductive alkylation of secondary heterocyclic amines}

Amine 1 or $2(10 \mathrm{mmol})$ was added to a stirred methanol solution $(10 \mathrm{~mL})$ of aldehyde 3 or 4 (10 $\mathrm{mmol})$ at $0--5{ }^{0} \mathrm{C}$. After $40 \mathrm{~min} \mathrm{AcOH}(20 \mathrm{mmol})$ was added and resulting mixture was stirred at $0--5{ }^{0} \mathrm{C}$ for $1 \mathrm{~h}$ and at $60{ }^{\circ} \mathrm{C}$ for $2 \mathrm{~h}$. After cooling to room temperature the resulting solution was added to a stirred and cooled $\left(0{ }^{\circ} \mathrm{C}\right)$ mixture of $\mathrm{NaBH}_{4}(20 \mathrm{mmol})$, benzene $(10 \mathrm{~mL})$ and acetic acid $(60 \mathrm{mmol})$. The stirring was continued for $30 \mathrm{~min}$ at room temperature, than for 10 $12 \mathrm{~h}$ under reflux. Reaction results were evaluated by TLC. Then reaction mixture was cooled and completely evaporated off under reduced pressure, the residue was treated with water and acidified to $\mathrm{pH} 1.0$. After extraction with AcOEt $(2 \times 20 \mathrm{~mL})$, the aqueous part was neutralized with $30 \% \mathrm{NaOH}$ to $\mathrm{pH} 7.0-8.0$. The corresponding amines 7-9 were extracted with AcOEt $(3 \times 50$ $\mathrm{ml}$ ) and after evaporation of AcOEt were not needed in purification.

Methyl 4-[(4-methylpiperazin-1-yl)methyl]benzoate (7). According to the general procedure amine 1 (1.0g, $10 \mathrm{mmol})$, aldehyde $3(1.64 \mathrm{~g}, 10 \mathrm{mmol})$ in methanol $(30 \mathrm{~mL})$ were reacted for 10 h. After extraction $7(1.86 \mathrm{~g}, 75 \%)$ was obtained as light yellow oily liquid. IR (film, $\left.\mathrm{cm}^{-1}\right)$ : 3200-3400, 1735, 1280, 755, 610; ${ }^{1} \mathrm{H}$ NMR (500MHz, $\left.\mathrm{CDCl}_{3}\right): \delta 2.30\left(3 \mathrm{H}, \mathrm{s}, \mathrm{CH}_{3}-\mathrm{N}\right), 2.48(8 \mathrm{H}$, m, $\mathrm{CH}_{2}$ piperazine), $3.57\left(2 \mathrm{H}, \mathrm{s}, \mathrm{CH}_{2} \mathrm{Ar}\right), 3.92(3 \mathrm{H}, \mathrm{s}, \mathrm{OMe}), 7.43(2 \mathrm{H}, \mathrm{d}, J=8.0 \mathrm{~Hz}), 7.99(2 \mathrm{H}$, $\mathrm{d}, J=8.0 \mathrm{~Hz}) ;{ }^{13} \mathrm{C} \mathrm{NMR}\left(125 \mathrm{MHz}, \mathrm{CDCl}_{3}\right) \delta: 45.99 ; 51.90 ; 53.06 ; 55.02 ; 62.52 ; 128.21 ; 128.87$; 129.46; 143.78; 167.05. MS m/z: $248\left(M^{+}, 90 \%\right), 149\left(\mathrm{M}-\mathrm{NC}_{4} \mathrm{H}_{8} \mathrm{NCH}_{3}, 100 \%\right), 99\left(\mathrm{NC}_{4} \mathrm{H}_{8} \mathrm{NCH}_{3}\right.$, $80 \%$ ); Anal.Calcd. for $\mathrm{C}_{14} \mathrm{H}_{20} \mathrm{~N}_{2} \mathrm{O}_{2}$ : C 67.74; $\mathrm{H}$ 8.06; N 11.29. Found: C 67.54; H 7.98; N 11.59.

1-Methyl-4-(4-nitrobenzyl)piperazine (8). According to the general procedure amine 1 (1.0 g, $10 \mathrm{mmol})$, aldehyde $4(1.51 \mathrm{~g}, 10 \mathrm{mmol})$ in methanol $(30 \mathrm{~mL})$ were reacted for $12 \mathrm{~h}$. After extraction 8 (1.1g, 47\%) was obtained as yellow oily liquid. IR (film, $\mathrm{cm}^{-1}$ ): 1650, 1595, 1525, 1420, 1345. ${ }^{1} \mathrm{H}$ NMR $\left(500 \mathrm{MHz}, \mathrm{CDCl}_{3}\right): \delta 2.26\left(3 \mathrm{H}, \mathrm{s}, \mathrm{CH}_{3}-\mathrm{N}\right), 2.46\left(8 \mathrm{H}, \mathrm{m}, \mathrm{CH}_{2}\right.$ piperazine), $3.56\left(2 \mathrm{H}, \mathrm{s}, \mathrm{CH}_{2} \mathrm{Ar}\right), 7.48(2 \mathrm{H}, \mathrm{d}, J=8.0 \mathrm{~Hz}), 8.14(2 \mathrm{H}, \mathrm{d}, J=8.0 \mathrm{~Hz})$. MS m/z: $235\left(\mathrm{M}^{+}(90 \%)\right.$, 
$136\left(\left[\mathrm{M}-\mathrm{N}\left(\mathrm{CH}_{2}\right)_{4} \mathrm{NMe}\right]^{+}, 100 \%\right), 99\left(\left[\mathrm{~N}\left(\mathrm{CH}_{2}\right)_{4} \mathrm{~N}-\mathrm{Me}\right]^{+}, 90 \%\right)$. Anal.Calcd. for $\mathrm{C}_{12} \mathrm{H}_{17} \mathrm{~N}_{3} \mathrm{O}_{2}: \mathrm{C}$ 61.39; H 7.23; N 18.07. Found: C 61.29; H 7.19; N 17.87.

Methyl 4-(4-morpholine-4-yl)methylbenzoate (9). According to the general procedure amine 2 $(0.85 \mathrm{~g}, 10 \mathrm{mmol})$, aldehyde $3(1.64 \mathrm{~g}, 10 \mathrm{mmol})$ in methanol $(30 \mathrm{~mL})$ were reacted for $8 \mathrm{~h}$. After extraction 9 (1.6g, 70\%) was obtained as white oily liquid. IR (film, $\mathrm{cm}^{-1}$ ): $1740 ;{ }^{1} \mathrm{H}$ NMR $\left(500 \mathrm{MHz}, \mathrm{CDCl}_{3}\right): \delta 2.49(4 \mathrm{H}, \mathrm{m}), 3.77(4 \mathrm{H}, \mathrm{m}), 3.49\left(2 \mathrm{H}, \mathrm{s}, \mathrm{CH}_{2} \mathrm{Ar}\right), 3.95$ (3H, s, OMe), 7.42 $(2 \mathrm{H}, \mathrm{d}, J=6.0 \mathrm{~Hz}), 8.0(2 \mathrm{H}, \mathrm{d}, J=6.0 \mathrm{~Hz}) ; \mathrm{MS} \mathrm{m} / \mathrm{z}: 235\left(M^{+}, 55 \%\right), 204(45 \%), 149\left(\left[\mathrm{M}_{-} \mathrm{OC}_{4} \mathrm{H}_{8} \mathrm{~N}\right]\right.$, $100 \%$ ). Anal.Calcd. for $\mathrm{C}_{13} \mathrm{H}_{17} \mathrm{NO}_{3}$ : C 66.42; H 7.22; N 5.94. Found: C 66.66; H 7.12; N 6.0.

\section{General procedures for the redutive alkylation of aryl and heteroaromatic amines}

Procedure 1. Aldehyde $3(10 \mathrm{mmol})$ benzene or ethanol solution $(10 \mathrm{~mL})$ was added to amine 10-12 $(0.01 \mathrm{~mol})$ benzene solution $(30 \mathrm{~mL})$ at $40{ }^{\circ} \mathrm{C}$. After refluxing for $2 \mathrm{~h}$ the resulting solution was cooled down to room temperature and added to a stirred and cooled $\left(0{ }^{\circ} \mathrm{C}\right)$ mixture of $\mathrm{NaBH}_{4}(0.02 \mathrm{~mol})$, benzene $(10 \mathrm{~mL})$ and acetic acid $(6 \mathrm{mmol})$. The stirring was continued for 30 min at room temperature, than for $6 \mathrm{~h}$ under reflux. After cooling to room temperature the resulting precipitate was filtered off, the filtrate was treated with $20 \%$ aq. $\mathrm{NaOH}$ solution, the solid reaction product 16-18 was filtered, washed by water and recrystallized from ethanol or ethanol-benzene (1:1) mixture.

Procedure 2. Azomethine 13-15 (10 mmol) benzene solution $(30 \mathrm{ml})$ was added to above mentioned reducing system at $0{ }^{\circ} \mathrm{C}$ with stirring. The further reduction, isolation and purification of reaction products 16-18 were carried out as described in procedure 1.

Methyl 4-\{[(4-nitrophenyl)imino]methyl\}benzoate (13). According to general procedure ${ }^{12}, p$ nitroanilin 10 (1.38 g, $10 \mathrm{mmol})$ and methyl 4-formylbenzoate 3 (1.64 g, $10 \mathrm{mmol})$ in ethanol $(30 \mathrm{~mL})$ were reacted under reflux $1 \mathrm{~h}$. After recrystallization from ethanol $13(2.23 \mathrm{~g}, 78 \%)$ was obtained as yellow prisms, mp $168-169{ }^{\circ} \mathrm{C}$. IR $\left(\mathrm{KBr}, \mathrm{cm}^{-1}\right): 1722,1602,1585,1338 .{ }^{1} \mathrm{H}$ NMR (500 MHz, CDCl $)$ : $\delta 3.87(3 \mathrm{H}, \mathrm{s}, \mathrm{OMe}), 7.29(2 \mathrm{H}, \mathrm{d}, J=8.4 \mathrm{~Hz}), 7.42(2 \mathrm{H}, \mathrm{d}, J=8.4 \mathrm{~Hz})$, $7.68(2 \mathrm{H}, \mathrm{d}, J=8.2 \mathrm{~Hz}), 7.94(2 \mathrm{H}, \mathrm{d}, J=8.2 \mathrm{~Hz}), 8.58(1 \mathrm{H}, \mathrm{s}, \mathrm{HC}=\mathrm{N}) ;{ }^{13} \mathrm{C}$ NMR $\left(125 \mathrm{MHz}, \mathrm{CDCl}_{3}\right)$ $\delta: 51.71,121.32,129.00,130.10,131.43,132.30,137.54,144.92,154.30,159.71,166.12$; MS m/z: $284\left(\mathrm{M}^{+}, 25 \%\right), 253(40 \%), 148\left(\left[\mathrm{M}-\mathrm{C}_{6} \mathrm{H}_{4} \mathrm{CO}_{2} \mathrm{CH}_{3}\right], 50 \%\right), 135\left(\mathrm{C}_{6} \mathrm{H}_{4} \mathrm{CO}_{2} \mathrm{CH}_{3}, 30 \%\right), 122$ $\left(\mathrm{C}_{6} \mathrm{H}_{4} \mathrm{NO}_{2}, 20 \%\right), 77\left(\mathrm{C}_{6} \mathrm{H}_{5}, 100 \%\right)$. Anal. Calcd. for $\mathrm{C}_{15} \mathrm{H}_{12} \mathrm{~N}_{2} \mathrm{O}_{4}: \mathrm{C}$ 63.38; H 4.23; N 9.86. Found: C 63.19; H 3.98; N 9.62.

Methyl 4-[(6-quinolinylimino)methyl]benzoate (14). According to general procedure ${ }^{12}$, 6quinolinamine 11 (1.44 g, $10 \mathrm{mmol})$ and 4-formylbenzoate 3 (1.64 g, $10 \mathrm{mmol})$ in butanol (30 $\mathrm{mL}$ ) were reacted under reflux $20 \mathrm{~min}$. After recrystallization 14 (2.32 g, $80 \%)$ was obtained as off-white solid, mp $156^{\circ} \mathrm{C}$, lit. ${ }^{12} 156-157^{\circ} \mathrm{C}$. The ${ }^{1} \mathrm{H}$ NMR, IR and mass spectra are identical with reported in literature ${ }^{12}$.

Methyl 4-[(E)-(\{4-methyl-3-[(4-pyridin-3-ylpyrimidin-2-yl)amino]phenyl\}imino)methyl]benzoate (15). According to general procedure ${ }^{12}$, 4-methyl- $N^{3}$-(4-pyridin-3-ylpyrimidin-2yl)benzene-1,3-diamine 12 (277 mg, $1 \mathrm{mmol}$ ) and methyl 4-formylbenzoate 3 (164 mg, $1 \mathrm{mmol}$ ) in ethanol $(20 \mathrm{ml})$ were reacted under reflux $3 \mathrm{~h}$. After recrystallization from ethanol $15(0.315 \mathrm{~g}$, 
$75 \%$ ) was obtained as yellowish-white needles, mp 131-132 ${ }^{\circ} \mathrm{C}$. IR $\left(\mathrm{KBr}, \mathrm{cm}^{-1}\right): 3449,1714$, 1600. ${ }^{1} \mathrm{H}$ NMR $\left(500 \mathrm{MHz}, \mathrm{CDCl}_{3}\right): \delta 2.40(3 \mathrm{H}, \mathrm{s}, \mathrm{Me}), 3.96(3 \mathrm{H}, \mathrm{s}, \mathrm{OMe}), 7.00(1 \mathrm{H}, \mathrm{dd}, J=7.9$, $1.9 \mathrm{~Hz}), 7.11(1 \mathrm{H}, \mathrm{s}), 7.20(1 \mathrm{H}, \mathrm{d}, J=5.2 \mathrm{~Hz}), 7.26(1 \mathrm{H}, \mathrm{d}, J=3.9 \mathrm{~Hz}), 7.41(1 \mathrm{H}, \mathrm{dd}, J=7.9,4.8$ $\mathrm{Hz}), 8.01(2 \mathrm{H}, \mathrm{d}, J=8.2 \mathrm{~Hz}), 8.13(2 \mathrm{H}, \mathrm{d}, J=8.2 \mathrm{~Hz}), 8.21(1 \mathrm{H}, \mathrm{d}, J=1.3 \mathrm{~Hz}), 8.38(1 \mathrm{H}, \mathrm{d}, J=$ $8.2 \mathrm{~Hz}), 8.54(1 \mathrm{H}, \mathrm{d}, J=5.1 \mathrm{~Hz}), 8.62(1 \mathrm{H}, \mathrm{s}), 8.72(1 \mathrm{H}, \mathrm{dd}, J=4.8,1.3 \mathrm{~Hz}), 9.29(1 \mathrm{H}, \mathrm{d}, J=1.8$ $\mathrm{Hz}) ;{ }^{13} \mathrm{C} \mathrm{NMR}\left(125 \mathrm{MHz}, \mathrm{CDCl}_{3}\right) \delta: 17.99,52.47,108.54,113.54,116.86,123.77,126.58$, $128.79,130.10,131.21,132.30,132.82,134.61,138.17,140.31,148.71,150.18,151.72,158.63$, 159.30, 160.73, 162.76, 166.80; Anal. Calcd. for $\mathrm{C}_{25} \mathrm{H}_{21} \mathrm{~N}_{5} \mathrm{O}_{2}$ : C 70.92; $\mathrm{H} 4.96 ; \mathrm{N}$ 16.55. Found: C 70.58; H 4.71 N 16.12.

Methyl 4-\{[(4-nitrophenyl)amino]methyl\}benzoate (16). According to general procedures 1, 2, p-nitroanilin 1 (1.38 g, $10 \mathrm{mmol})$ and methyl 4-formylbenzoate 3 (1.64 g, $10 \mathrm{mmol})$ or methyl 4$\{[(4-n i t r o p h e n y l) i m i n o] m e t h y l\}$ benzoate $13(2.84 \mathrm{~g}, 10 \mathrm{mmol})$ were reacted with $\mathrm{NaBH}_{4}(0.76 \mathrm{~g}$, $20 \mathrm{mmol})$ in $\mathrm{AcOH}(3.6 \mathrm{~g}, 60 \mathrm{mmol})$ and benzene - ethanol mixture $1: 1(40 \mathrm{ml})$ at $20{ }^{\circ} \mathrm{C}$ for 30 min and under reflux for $6 \mathrm{~h}$. After recrystallization from ethanol-benzene mixture (1:1) 16 (2.0 g, $74 \%$ by procedure $1,1.9 \mathrm{~g}, 66 \%$ by procedure 2 ) was obtained as yellow crystals, mp 166$167^{\circ} \mathrm{C}$. IR ( $\left.\mathrm{KBr}, \mathrm{cm}^{-1}\right): 3391,1705,1599,1335\left(\mathrm{NO}_{2}\right) .{ }^{1} \mathrm{H}$ NMR (500 MHz, DMSO-d 6 ) $\delta: 3.96$ $(3 \mathrm{H}, \mathrm{s}, \mathrm{OMe}), 4.50(2 \mathrm{H}, \mathrm{d}, J=5.2 \mathrm{~Hz}), 6.58(2 \mathrm{H}, \mathrm{d}, J=9.3 \mathrm{~Hz}), 6.75(1 \mathrm{H}, \mathrm{t}, J=5.2 \mathrm{~Hz}, \mathrm{NH}), 7.42$ $(2 \mathrm{H}, \mathrm{d}, J=8.7), 8.02(4 \mathrm{H}, \mathrm{m}) ;{ }^{13} \mathrm{C} \mathrm{NMR}\left(125 \mathrm{MHz}, \mathrm{DMSO}-\mathrm{d}_{6}\right) \delta: 46.29,51.57,110.77,125.74$, $126.50,128.78,129.51,137.11,143.07,153.27,166.00 ; \mathrm{MS} \mathrm{m} / \mathrm{z}: 286\left(\mathrm{M}^{+}, 15 \%\right), 135$ $\left(\mathrm{C}_{6} \mathrm{H}_{4} \mathrm{CO}_{2} \mathrm{CH}_{3}, 30 \%\right), 122\left(\mathrm{C}_{6} \mathrm{H}_{4} \mathrm{NO}_{2}, 20 \%\right), 77\left(\mathrm{C}_{6} \mathrm{H}_{5}, 100 \%\right)$. Anal. Calcd. for $\mathrm{C}_{15} \mathrm{H}_{14} \mathrm{~N}_{2} \mathrm{O}_{4}: \mathrm{C}$ 62.94; H 4.90; N 9.79. Found: C 62.58; H 4.71; N 9.43.

Methyl 4-[(6-quinolinylamino)methyl]benzoate (17). According to general procedures 1, 2, 6quinolinamine 11 (1.44 g, $10 \mathrm{mmol}$ ) and methyl 4-formylbenzoate 3 (1.64 g, $10 \mathrm{mmol}$ ) or methyl 4-[(quinolin-6-ylimino)methyl]benzoate $12(2.90 \mathrm{~g}, 10 \mathrm{mmol})$ were reacted with $\mathrm{NaBH}_{4}(0.76 \mathrm{~g}$, $20 \mathrm{mmol})$ in $\mathrm{AcOH}(3.6 \mathrm{~g}, 60 \mathrm{mmol})$ and benzene or benzene - ethanol mixture 1:1 (40 ml) at $20^{\circ} \mathrm{C}$ for $30 \mathrm{~min}$ and under reflux for $6 \mathrm{~h}$. After recrystallization from ethanol $17(2.22 \mathrm{~g}, 76 \%$ by procedure 1, $2.05 \mathrm{~g}, 70 \%$ by procedure 2) was obtained as off-white solid crystals, mp 189$190{ }^{\circ} \mathrm{C}$. IR (KBr, cm $\left.{ }^{-1}\right): 3246,1720 .{ }^{1} \mathrm{H}$ NMR (500MHz, DMSO-d 6 ): $\delta 3.82(3 \mathrm{H}, \mathrm{s}, \mathrm{OMe}), 4.45$ $\left(2 \mathrm{H}, \mathrm{s}, \mathrm{CH}_{2}\right), 6.50(1 \mathrm{H}, \mathrm{d}, J=2.2 \mathrm{~Hz}), 6.61$ (br s, $\left.1 \mathrm{H}, \mathrm{NH}\right), 7.21(1 \mathrm{H}, \mathrm{dd}, J=8.2,4.2 \mathrm{~Hz}), 7.26$ $(1 \mathrm{H}, \mathrm{dd}, J=9.1,2.2 \mathrm{~Hz}), 7.46(2 \mathrm{H}, \mathrm{d}, J=8.3 \mathrm{~Hz}), 7.72(1 \mathrm{H}, \mathrm{d}, J=9.1 \mathrm{~Hz}), 7.83(1 \mathrm{H}, \mathrm{d}, J 8.2$ $\mathrm{Hz}), 7.90(\mathrm{~d}, 2 \mathrm{H}, J=8.3 \mathrm{~Hz}), 8.44(\mathrm{~d}, 1 \mathrm{H}, J=3.1 \mathrm{~Hz}) .{ }^{13} \mathrm{C}$ NMR $(125 \mathrm{MHz}$, DMSO-d 6$) \delta: 45.65$, 50.52 , 120.31, 122.31, 125.23, 126.56, 127.34, 128.87, 129.13, 130.11, 131.20, 136.12, 141.78, 143.67, 148.54, 166.45; Anal. Calcd. for $\mathrm{C}_{18} \mathrm{H}_{16} \mathrm{~N}_{2} \mathrm{O}_{2}$ : C 73.97; H 5.48; N 9.60. Found: C 73.62; H 5.29; N 9.33 .

Methyl 4-[(\{4-methyl-3-[(4-pyridin-3-ylpyrimidin-2-yl)amino]phenyl\}amino)methyl]benzoate (18). According to general procedures 1, 2 4-methyl- $\mathrm{N}^{3}$-(4-pyridin-3-ylpyrimidin-2yl)benzene-1,3-diamine 12 (277 mg, $1 \mathrm{mmol}$ ) and methyl 4-formylbenzoate 3 (164 mg, $1 \mathrm{mmol}$ ) or methyl 4-\{[(4-methyl-3-\{[4-(3-pyridinyl)-2-pyrimidinyl $]$ amino $\}$ phenyl)imino $]$ methyl $\}$ benzoate 15 (423 mg, $1 \mathrm{mmol})$ were reacted with $\mathrm{NaBH}_{4}(76 \mathrm{mg}, 2 \mathrm{mmol})$ in AcOH $(0.36 \mathrm{~g}, 6$ $\mathrm{mmol})$ and benzene - ethanol mixture $1: 1(20 \mathrm{ml})$ at $20{ }^{\circ} \mathrm{C}$ for $30 \mathrm{~min}$ and under reflux for $6 \mathrm{~h}$. 
After recrystallization from ethanol $18(255 \mathrm{mg}, 76 \%$ by procedure 1 and $271 \mathrm{mg}, 64 \%$ by procedure 2) was obtained as yellow solid, $\mathrm{mp} 153-154^{\circ} \mathrm{C}$. IR $\left(\mathrm{KBr}, \mathrm{cm}^{-1}\right): 3246,1720 .{ }^{1} \mathrm{H} \mathrm{NMR}$ $\left(500 \mathrm{MHz}, \mathrm{CDCl}_{3}\right): \delta 2.25(3 \mathrm{H}, \mathrm{s}, \mathrm{Me}), 3.88(3 \mathrm{H}, \mathrm{s}, \mathrm{OMe}), 4.42(2 \mathrm{H}, \mathrm{s}), 6.42(1 \mathrm{H}, \mathrm{d}, \mathrm{J}=5.0 \mathrm{~Hz})$, $6.99(1 \mathrm{H}, \mathrm{dd}, \mathrm{J}=8.0,1.9 \mathrm{~Hz}), 7.10(1 \mathrm{H}, \mathrm{s}), 7.22(1 \mathrm{H}, \mathrm{d}, \mathrm{J}=4.8 \mathrm{~Hz}), 7.29(1 \mathrm{H}, \mathrm{t}, \mathrm{J}=4.1 \mathrm{~Hz})$, $7.39(1 \mathrm{H}, \mathrm{dd}, \mathrm{J}=8.0,4.8 \mathrm{~Hz}), 7.49(1 \mathrm{H}, \mathrm{d}, \mathrm{J}=5.1 \mathrm{~Hz}), 7.60(2 \mathrm{H}, \mathrm{d}, \mathrm{J}=8.2 \mathrm{~Hz}), 7.96(2 \mathrm{H}, \mathrm{d}, \mathrm{J}=$ $8.2 \mathrm{~Hz}), 8.30(1 \mathrm{H}, \mathrm{d}, \mathrm{J}=8.0 \mathrm{~Hz}), 8.58(1 \mathrm{H}, \mathrm{s}), 8.70(1 \mathrm{H}, \mathrm{dd}, \mathrm{J}=4.7,1.9 \mathrm{~Hz}), 9.25(1 \mathrm{H}, \mathrm{s}) ;{ }^{13} \mathrm{C}$ NMR $\left(125 \mathrm{MHz}, \mathrm{CDCl}_{3}\right) \delta: 19.29,34.54,51.77,102.54,103.54,106.86,118.88,123.87,127.58$, 129.79, 130.00, 131.81, 132.82, 134.11, 141.17, 143.51, 147.91, 149.72, 150.18, 157.55, 159.30, 165.98, 168.45; Anal. Calcd. for $\mathrm{C}_{25} \mathrm{H}_{23} \mathrm{~N}_{5} \mathrm{O}_{2}$ : C 70.59; H 5.41; N 16.47. Found: C 70.78; H 5.30 N 16.62.

\section{Acknowledgements}

The authors thank Dr A. Baranovskii for NMR spectroscopic measurements. Financial support provided by BRFFR, Grant X07-110 is greatly appreciated.

\section{References and Notes}

1. (a) Reits, A. B.; Bennett, D. J.; Blum, P. S.; Codd, E. E.; Maryanoff, C. A.; Ortegon, M. E.; Renzi, M. J.; Ascott, M. K.; Shank, R. P.; Vaught, J. L. J. Med. Chem. 1994, 37, 1060. (b) Zhuang, Z.-P; Kung, M. P.; Kung, H. P. J. Med .Chem. 1994, 37, 1406. (c) Szakacs, Z.; Beni, S.; Vagra, Z.; Orfi, L.; Keri, G.; Noszal, B. J. Med. Chem. 2005, 48, 249. (d) Arasasinghan, P. N.; Fotsch, C.; Ouyang, X.; Norman, M. H.; Kelly, M. B.; Staerk, K. L.; Karbon, B.; Hale, C.; Baumgart, J. V.; Zambrano, M.; Cheetham, J.; Tamago, N. A. J. Med. Chem. 2003, 46, 9. (e) Horton, D. A.; Bourne, G. T.; Smythe, M. L. Chem. Rev. 2003, 103, 901.

2. (a) Venable, J. D.; Chai, W.; Dvorak, C. A.; Grice, C. A.; Jablonowski, J.; Shah, A. C. R.; Kwok, A. K.; Ly, K. S.; Pio, B.; Wei, J.; Desai, P. J.; Jiang, W.; Nguyen, S.; Ling, P.; Wilson, S. J.; Dunford, P.J.; Thurmond, R. L.; Lovenberg, T. W.; Karlsson, L.; Carruthers, N. I.; Edwards, J. P. J. Med. Chem. 2005, 48, 8289. (b) Andersen, K.; Lifjefors, T.; Gundetoffe K.; Perreguard, J.; Bogeso, K. P. J. Med. Chem. 1994, 37, 950. (c) EnguehardGueiffier, C.; Hübner, H.; Hakmaoui, Ah.; Allouchi, H.; Gmeiner, P.; Argiolas, A.; Melis, M. R.; Gueiffier, A. J. Med. Chem. 2006, 49, 3938. (d) Romero, D. L.; Busso, M.; Tan, CK.; Reusser, F.; Palmer, Aristoff, P. A.; So, A. G.; Resnick, L.; Tarplay, W. G. Proc. Natl. Acad. Sci .U.S.A. 1991, 88, 8806. (e) Leopoldo, M.; de Giorgio, P.; Berardi, F.; Lacivita, E.; Colabuto, N.A.; Perrone, R.; Tortorella, V. J. Med. Chem. 2002, 45, 5727.

3. (a) Kozlov, N. G.; Gusak, K. N.; Tkachev, A. A. Khim. Geterotsyklich. Soed. 2007, 877.

(b) Kozlov, N. G.; Koroleva, E. V.; Ignatovich, J. V.; Gusak, K. N; Kadutskii, A. P. Zh. 
Org. Khim. 2007, 43, 902. (c) Kozlov, N. G.; Tereshko, A. B.; Gusak, K. N. Zh. Org. Khim. 2006, 42, 281. (d) Kozlov, N. G.; Pashkovskii, F. S.; Gusak, K. N.; Koroleva, E. V.; Tereshko, A. B.; Lokot, I. P. Zh. Org. Khim. 2004, 40, 584. (e) Kadutskii, A.; Kozlov, N. Synlett 2006, 1349. (f) Koroleva, E. V.; Ignatovich, J. V.; Gusak, K. N. The Second International Symposium on Structure and Function of Biomolecules, Minsk, Belarus, October 3-4, 2006:Abstract No. PR-65.

4. (a) Sairam, P.; Puranik, R.; Kelkar, A. S.; Sasikiran S.; Veerender, M.; Parvathi, A. Synthetic. Comm. 2003, 33, 3597. (b) Monge, A.; Pena, M.; Palop, J. A.; Cardera, J. M.; Rosa, J.; Garcia, E.; Romero, G.; Rio, J; Lasheras, B. J. Med. Chem. 1994, 37, 1320.

5. (a) Wright, W. B. J. Org. Chem. 1962, 27, 1042. (b) Paul, R.; Hallet, W. A.; Hannifin, J. W.; Reich, M. R.; Johnson, B. D.; Lenhard, R. H.; Dusza, J. P.; Kerwar, S. S.; Lin, Y.; Picett, W. C.; Seifert, C. M.; Torley, L. W.; Tarrant, M. E.; Wrenn, S. J. Med. Chem. 1993, 36, 2716. (c) Romero, D. L.; Morge, R. A.; Biles, C.; Berrios-Pena, N.; May, P. D.; Palmer, J. R.; Johnson, P. D.; Smith, G. W.; Busso, M.; Tan, C-K.; Voorman, R.; Reusser, F.; Downey, K. M.; So, A. G.; Tarplay, W. G.; Aristoff, P. A. J. Med. Chem. 1994, 37, 999.

6. (a) Regnier, G. L.; Cavenary, R. J.; Laubie, M. J.; LeDouary, J. C. J. Med. Chem. 1968, 11, 1151. (b) Hitchins, R. O.; Kandasamy, D. J. Org. Chem. 1981, 46, 3571. (c) Prasab, R. N.; Hawkins, L. R.; Tietje, K. J. Med. Chem. 1968, 11, 1144. (d) Tarasevich, V. A.; Kozlov, N. G. Russ. Chem. Rev. 1999, 68, 55.

7. (a) Saxena, I.; Borah, R.; Sarma, J.C. J. Chem. Soc., Perkin Trans. 1 2000, 503. (b) Borch, R. F.; Bernstein, M. D.; Durst, H. D. J. Am. Chem. Soc. 1971, 93, 2897. (c) Bailey, H. V.; Heaton, W.; Vicker, N.; Potter, B. V. L. Synlett 2006, 2444. (d) Micovic, I. V.; Ivanovic, D. M.; Paitak, D. M.; Bojic, V. D. Synthesis 1991, 1043. (e) Mattson, R. J.; Pham, K. M.; Leuck, D. J.; Cowen, K. A. J. Org. Chem. 1990, 55, 2552. (f) Abdel-Magid, A. F.; Carson, K. G.; Harris, B. D.; Maryanoff, C. A.; Shah, R. D. J. Org. Chem. 1996, 61, 3849. (g) Saidi, M. R.; Brown, R. S.; Ziyaei-Halmjani, A. J. Iran. Chem. Soc. 2007, 4, 194. (h) Gribble, G. W.; Jasinski, J. M.; Pellicone, J. T.; Panetta, J. A. Synthesis 1978, 766. (i) Bhattacharyya, S.; Neidigh, K. A.; Avery, M. A.; Williamson, J. S. Synlett 1999, 1781.

8. (a) Ignatovich, J. V.; Gusak, K. N.; Chernikhova, T. V.; Kozlov, N. G.; Koroleva, E. V. Chem. Heterocycl. Comp. (Russ.) 2007, 12, 1820. (b) Ignatovich, J. V. Izvestiya of NAN Belarus, Ser. Khim. 2006, 5, 56.

9. (a) Gravotto, G.; Nanj, G. M.; Tagliapietra, S. J. Org. Chem. 2003, 68, 1731. (b) Chen, B.C.; Sundeen, J. E.; Guo, P.; Bednarz, M. S.; Zhao, R. Tetrahedron Lett. 2001, 42, 1245.

10. Marchini, P.; Liso, G.; Reho, A. J. Org. Chem. 1975, 23, 3453.

11. Schellenberg, K. A. J. Org. Chem. 1963. 28, 3259.

12. Gusak, K. N.; Tereshko, A. B.; Kozlov, N. G. Zn. Obsch. Khim. (Russ.) 2000, 70, 320. 